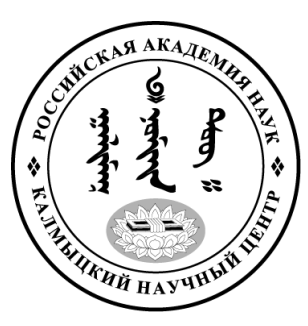

Published in the Russian Federation

Oriental Studies (Previous Name: Bulletin of the Kalmyk Institute for

Humanities of the Russian Academy of Sciences)

Has been issued as a journal since 2008

ISSN: 2619-0990; E-ISSN: 2619-1008

Is. 4, pp. 634-644, 2019

DOI: $10.22162 / 2619-0990-2019-44-4-634-644$

Journal homepage: https://kigiran.elpub.ru

УДК 94 (47) $07+073+081+082+083$

\title{
Роль торгово-ремесленного населения в создании стационарных поселений на землях казахов Внутренней киргизской орды Астра- ханской губернии. XIX в.
}

Сергей Степанович Белоусов ${ }^{1}$

${ }^{1}$ Калмыцкий научный центр РАН (д. 8, ул. им. И. К. Илишкина, 358000 Элиста, Российская Федерация)

кандидат исторических наук, старший научный сотрудник

ORCID: 0000-0001-7614-3516.E-mail: sbelousovelista@mail.ru

\begin{abstract}
Аннотация. Введение. Тема участия и роли торгово-ремесленного населения в создании на землях Внутренней орды стационарных поселений не нашла достаточного отражения в отечественной историографии, хотя её изучение позволяет глубже познать многие процессы, происходившие в XIX в. на территории Западного Казахстана. С данной темой связаны вопросы формирования населения, российской политики на национальных окраинах, миграционная проблематика и др. Главная цель статьи - показать вклад торгово-ремесленного переселенческого населения в процесс создания первых стационарных поселений в казахских кочевьях междуречья Волги и Урала, в этой связи ставятся задачи: выявить причины появления торгово-ремесленного населения на территории Внутренней орды, определить его национальный, сословный и профессиональный состав, проанализировать отношение к переселенцам со стороны казахского населения и властей и последствия переселенческого движения для развития региона. Результаты. Автором выявлены причины появления торгово-ремесленного населения на землях букеевских казахов, определены его национальный, сословный и профессиональный состав, проанализировано отношение к переселенцам со стороны местного отношения и властей и последствия переселенческого движения для развития региона. Преобладание среди переселенцев людей, занимающихся торговлей и ремесленной деятельностью, автор объясняет непривлекательностью для земледельческого населения степных пространств между Волгой и Уралом, в массе своей непригодных из-за своих природных свойств и климата для успешного культивирования земледельческой отрасли. По этой причине созданные на землях Внутренней киргизской орды поселения по роду занятий их жителей носили ярко выраженный характер торгово-ремесленных. К благоприятным условиям следует отнести и то, что казахская знать и казахское общество в целом проявляли заинтересованность в развитии торговли, в связи с чем принимались меры стимулирующего характера для привлечения торговцев, и отсутствие у кочевников своего профессионального слоя торговцев, что исключало, во всяком случае, на первых порах конкуренцию между старожильческим и пришлым населением. Автор отмечает, что высшее российское руководство не проявляло большого интереса к землям букеевских казахов, поскольку через них не проходили стратегически важные пути сообщения и ещё не были разведаны месторождения природных ископаемых, могущие быть использованными в промышленных целях. В XIX в. власти не стремились изменить уклад жизни букеевских казахов, и потому не видели необходимости в осуществлении мер по пере-
\end{abstract}


воду их на оседлый образ жизни. По этой и другим причинам стационарных поселений было основано немного, а костяк их жителей составили переселенцы из других губерний. Среди основателей поселков преобладали торговцы-татары из Казанской губернии, которые были близки к казахам по языку и религии. Одним из важных следствий проникновения татар на территорию Внутренней киргизской орды стало усиление пропаганды ислама и укрепление его позиций среди казахского населения. Bblвoдbl. По результатам исследования автор приходит к выводу о том, что торговцы-переселенцы сыграли главную роль в создании и развитии оседлых поселений в XIX в. на территории Внутренней киргизской орды. Появление их на землях букеевских казахов не было связано с целенаправленной политикой российского руководства и буржуазии, а вызвано благоприятными условиями, сложившимися в данном регионе для торговой деятельности в XIX в. Торговцы и ремесленники положили начало созданию стационарных поселений на землях букеевских казахов, способствовали развитию торговли и ремесел, приобщению кочевников к данным занятиям и к оседлому образу жизни.

Ключевые слова: Астраханская губерния, Внутренняя киргизская орда, казахи, торгово-ремесленное население, переселения

Благодарности. Исследование проведено в рамках государственной субсидии - проект «Комплексное исследование процессов общественно-политического и культурного развития народов Юга России» (№ госрегистрации: АААА-А-19-119011490038-5).

Для цитирования: Белоусов С. С. Роль торгово-ремесленного населения в создании стационарных поселений на землях казахов Внутренней киргизской орды Астраханской губернии. XIX в. Oriental Studies. 2019;(4):634-644. DOI: 10.22162/2619-0990-2019-44-4-634-644.

UDC 94 (47) $07+073+081+082+083$

\title{
The Inner Kirghiz Horde of Astrakhan Governorate: the Impact of Trades and Crafts People on the Establishment of Stationary Settlements in Kazakh-Inhabited Lands. $1^{\text {th }}$ Century
}

\author{
Sergey S. Belousov ${ }^{l}$ \\ ${ }^{1}$ Kalmyk Scientific Center of the RAS (8, Ilishkin St., Elista 358000, Russian Federation) \\ Cand. Sc. (History), Senior Research Associate \\ ORCID: 0000-0001-7614-3516. E-mail: sbelousovelista@mail.ru
}

\begin{abstract}
Introduction. The impact and role of trades and crafts population in the establishment of stationary settlements throughout the Inner Kirghiz Horde remains understudied in domestic historiography though it might facilitate deeper insight into multiple processes that took place in western Kazakhstan in the 19th century. The topic is closely related to the issues of population formation, Russia's policy in national peripheries, migrations, etc. Goals. The article primarily aims to illustrate the participation of trades and crafts people in the establishment of earliest settlements in Kazakh nomadic territories of the Volga-Ural interfluve, which includes a number of objectives, such as to specify the causes underlying the arrival of trades and crafts people in the lands of the Bukey Horde; examine their national, class and occupational characteristics; analyze the attitude of local inhabitants and authorities to the immigrants, and delineate some consequences of the migration for the development of the region. Results. The paper shows the fact those were predominantly trades and crafts people who settled there is explained by that due to certain natural and climate properties the steppe territories between the Volga and the Don rivers were by and large unsuitable for successful crop growing and, thus, unattractive for agricultural population. For this reason, the settlements established within the Inner Kirghiz Horde served - by the occupational profile of its inhabitants - as trade and handicraft centers. The favorable conditions included the interest of the Kazakh nobility and Kazakh community in the development of trade, which gave way to stimulating measures aiming to attract traders, and the absence of professional traders among the nomads as such that excluded - at least, in the early stage - competition between the natives and newcomers. The paper also notes that the Russian ruling circles showed no essential interest in the lands of the Bukey Kazakhs since those were not crossed by any strategically important routes, nor any deposits
\end{abstract}


of natural resources that could be used for industrial purposes had been discovered yet. In the 19th century, the authorities did not seek to change lifestyles of the Bukey Kazakhs, and therefore took no measures to sedentarize them. For this and other reasons, permanent settlements there were few enough, the bulk of their inhabitants being migrants from other provinces. The majority of those to have founded villages were Tatars from Kazan Governorate who were close to the Kazakhs both in terms of language and religion. An important consequence of the Tatars' penetration in the Inner Kirghiz Horde was the intensification of Islamic propaganda and strengthening of Islam's positions among the Kazakh population. Conclusions. The study concludes that migrant traders played a major role in the creation and development of the earliest 19th-century stationary settlements in the territory of the Inner Kyrgyz Horde. Their arrival was not associated with any special policy of the Russian Government and the bourgeoisie but resulted from favorable trade conditions that prevailed in the territory. Merchants and craftsmen gave rise to permanent settlements in the lands of the Bukey Kazakhs, facilitating further development of trade and crafts, familiarizing the nomads with the mentioned activities and sedentary life.

Keywords: Astrakhan Governorate, Inner Kirghiz Horde, Kazakhs, trades and crafts population, resettlement

Acknowledgements: The reported study was funded by a government subsidy — project name 'Socio-Political and Cultural Development of South Russia's Peoples: a Comprehensive Research of Respective Processes' (State Reg. No. AAAA-A19-119011490038-5).

For citation: Belousov S. S. The Inner Kirghiz Horde of Astrakhan Governorate: the Impact of Trades and Crafts People on the Establishment of Stationary Settlements in Kazakh-Inhabited Lands. $19^{\text {th }}$ Century. Oriental Studies. 2019;(4):634-644. DOI: 10.22162/2619-0990-2019-44-4-634-644.

\section{ङ}

\section{Введение}

В первые годы XIX столетия в степях междуречья Урала и Волги обосновался на постоянное жительство со своими подвластными казахский султан Букей, для которых была учреждена отдельная административно-территориальная единица в составе Астраханской губернии под названием Внутренняя киргизская орда. Казахи вели кочевой образ жизни и не имели своих стационарных поселений, поэтому их основателями в большинстве случаев стали представители других народов и сословий, переселившиеся на территорию Внутренней киргизской орды из других губерний. При этом следует отметить, что среди переселенцев доминировали торговцы и ремесленники, а сами поселения по роду занятий их жителей носили ярко выраженный характер торгово-ремесленных. Переселенцы привнесли в среду кочевников культуру оседлых поселений и сделали торгово-ремесленную деятельность одной из важнейших составляющих экономики Внутренней киргизской орды. На данное обстоятельство обратили внимание ещё дореволюционные исследователи Внутренней киргизской орды, среди которых наиболее подробные сведения оставили И. С. Иванов [Иванов 2001а: 140231], А. Евреинов [Евреинов 2001: 30-86], М. Я. Киттара [Киттара 2001: 5-38], Я. Альбрандт [Альбрандт 2001: 17-45], А. Поленов [Поленов 2001: 46-242].

В советский период большой вклад в разработку истории Внутренней киргизской орды внесли исследователи Б. А. Аспандияров [Аспандияров 2007] и С. З. Зиманов [Зиманов 1982], опубликовавшие по данной теме работы общего характера. Они и многие другие советские историки рассматривали переселенческое движение торговцев и ремесленников на земли Внутренней киргизской орды с позиций марксистско-ленинской теории, считая, что оно являлось инструментом сознательно проводившейся российским правительством политики по колониальному закабалению казахского населения и попыткой российской буржуазии утвердить своё господство на землях кочевников с целью превращения их в свой сырьевой придаток.

Советскими исследователями была проведена большая работа по изучению истории переселенческого движения в Казахстан и его отдельные регионы, однако по Внутренней киргизской орде специальных 
работ написано так и не было. В 1980-е гг. вышли монографии историка Н. Е. Бекмахановой «Формирование многонационального населения Казахстана и Северной Киргизии: последняя четверть XVIII - 60-е гг. XIX в.» [Бекмаханова 1980] и «Многонациональное население Казахстана и Киргизии в эпоху капитализма (60-е гг. XIX в. 1917 г.)» [Бекмаханова 1986], посвящённые формированию населения указанных регионов в имперский период, однако материалов по Внутренней киргизской орде в них содержится очень мало.

Обзор научной литературы показывает, что в отечественной историографии не существует специальных работ по вопросу переселений торгово-ремесленного населения на земли Внутренней орды и его роли в создании стационарных поселений. Между тем изучение данного вопроса представляет большой научный интерес, поскольку даёт возможность глубже понять как процесс формирования населения Западного Казахстана, так и более объективно оценить политику российского государства на одной из бывших его национальных окраин. Исследование данной темы, безусловно, будет полезным и для историков, специализирующихся на изучении миграционных процессов в досоветский период, поскольку оно позволит более углублённо познать общие закономерности и особенности проявления их в отдельных регионах.

Цель данной статьи - показать вклад торгово-ремесленного переселенческого населения в процесс создания первых стационарных поселений в казахских кочевьях междуречья Волги и Урала, в этой связи ставятся задачи: выявить причины появления торгово-ремесленного населения на территории Внутренней орды, определить его национальный, сословный и профессиональный состав, проанализировать отношение к переселенцам со стороны казахского населения и властей и последствия переселенческого движения для развития региона.

\section{Материалы}

При написании статьи были использованы фонды Российского государственного исторического архива (РГИА) и Государственного архива Астраханской области (ГА АО), в которых отложились документы органов государственной власти, в ведении которых находилась Внутренняя орда.
Ценными источниками также являются публиковавшиеся в ежегодных памятных книжках и иных сборниках Астраханского статистического комитета статистические материалы по населению, управлению и экономике Внутренней киргизской орды, статьи и заметки центральных губернских газет - «Астраханский листок» и «Астраханский вестник»; представляют интерес и публикации православного духовенства в журнале «Астраханские епархиальные ведомости», в котором священники делились личными впечатлениями о своих подопечных прихожанах и их взаимоотношениях с казахами и татарами-переселенцами.

Методологической базой исследования послужили историко-сравнительный и исторический методы, которые позволяют изучить процесс в динамике и в сравнительном аспекте.

\section{Основная часть}

До прихода казахов в первые годы XIX в. территория будущей Внутренней (Букеевской) киргизской орды не была затронута переселенческим движением и потому не имела стационарных поселений. Она не привлекала оседлое население, поскольку природные условия в ней в целом были неблагоприятными для проживания человека, не вызывала она большого интереса и у властей, так как находилась вне зоны пролегания путей сообщения стратегического значения и разработки месторождений природных ископаемых.

Возникновение во Внутренней киргизской орде первого стационарного поселения связано с именем его правителя - хана Джангира - находившегося у власти с 1823 по 1845 гг. В детстве будущий хан несколько лет провёл в доме Астраханского гражданского губернатора С. С. Андреевского, где усвоил некоторые стороны жизни российского дворянства. Осёдлый образ жизни понравился Джангиру, и, надо полагать, это обстоятельство повлияло на принятие им решения устроить себе резиденцию в стационарном поселении после того, как он вступил в управление Внутренней киргизской ордой.

В 1827 г. он исходатайствовал у российского руководства разрешение построить в степи, в 60 верстах от озера Эльтон, посёлок, который он задумал сделать административным центром Внутренней орды. 
В 1828 г. в нём возвели первые постройки и присвоили название «Ханская Ставка» (ныне г. Урда в Казахстане). Примеру хана последовали некоторые султаны, начавшие вслед за ним переезжать на жительство в посёлок, однако, несмотря на это, население его росло медленно.

Ханская Ставка получила толчок своему развитию после того, как в 1832 г. хан Джангир добился у российских властей разрешения на организацию постоянной стационарной торговли в Ханской Ставке. Важно отметить, что своих профессиональных торговцев у букеевских казахов было незначительное число, поэтому данную профессиональную нишу у них восполняли в основном представители других народов: татары, русские, армяне и др. Первоначально они торговали с казахами из населённых пунктов, расположенных на границе казахских кочевий, но затем начали углубляться в степь, постепенно перенося свои торговые операции непосредственно на территорию Внутренней орды [Аспандияров 2007: 91]. В первой трети XIX в. получила развитие «развозная торговля», когда торговцы разъезжали по степи с целью продажи или обмена своих промышленных и продовольственных товаров, взамен они приобретали у кочевников скот и продукцию животноводства. Безопасные условия торговли, большие прибыли, которые приносила торговля, а также покровительство ей со стороны хана Джангира благоприятствовали притоку во Внутреннюю киргизскую орду всё большего числа торговцев, некоторые из которых начали подумывать о возможности закрепления в ней на постоянное жительство.

Большое значение для развития торговли имел факт постоянной поддержки её ханом Джангиром. Именно благодаря ему стало возможным проникновение, а затем и устройство на постоянное жительство торговцев и ремесленников неказахского происхождения. Вообще на торговлю хан Джангир возлагал особенные надежды, прежде всего в деле постепенного приобщения своих подвластных к оседлому образу жизни. В 1839 г. он просил Николая I разрешить основать из пожелавших перейти на оседлость казахов 10 выселков и учредить в каждом из них по две ярмарки в год. Эти поселения должны были составить «зародыш будущих торговых местечек», дав толчок развитию торговли, и стать «постоянными точками правительственных распоряжений, а также пунктами для запасов в случае холода» [РГИА. Ф. 1291. Оп. 82. Д. 1. Л. 181]. В них планировалось привлечь на жительство врачей, ветеринаров, открыть больницы и другие гражданские учреждения. Этот план, однако, воплощён в жизнь не был.

Способствуя развитию торговли, хан Джангир, безусловно, руководствовался и личной выгодой. Как уже отмечалось, в детстве он несколько лет воспитывался в доме астраханского гражданского губернатора и усвоил некоторые стороны повседневности русских дворян, в частности жизнь на широкую ногу. Роскошный образ жизни приводил к большим денежным тратам, поэтому хану было выгодно привлекать в свою ставку людей, которые могли помочь ему покрыть расходы.

Что касается российских властей, то они не препятствовали Джангиру в проводимой им торговой политике, поскольку она их вполне устраивала. Она не вела к осложнению общественно-политической и социально-экономической обстановки во Внутренней орде, поскольку не предполагала изъятия земель у кочевников: торговцам в силу специфики их рода деятельности не требовалось большого количества земли, а если земля и была нужна, то в малом количестве и только тем из них, которые занимались стационарной торговлей в Ханской Ставке. Одним словом, торгово-ремесленный контингент поселян вполне устраивал и хана, и российские власти, поскольку был малочисленным и не стеснял в земельном отношении кочевников-казахов, постоянно жаловавшихся на недостаток земель.

Необходимо также учитывать и то, что в XIX в. высшее российское руководство не строило планов относительно изменения образа жизни казахов и использования части земель Внутренней киргизской орды под заселение крестьян или для других государственных и местных нужд. 23 декабря 1852 г. Оренбургский и Самарский генерал-губернатор В. П. Перовский писал министру государственных имущества П. Д. Киселеву про букеевских казахов: «Земледельческим население это, по качеству занимаемой ими земель, сделаться не может, да нет в том и никакой нужды для государства, которому гораздо выгоднее, 
чтобы киргизы навсегда оставались народом пастушеским» [История Букеевского ханства 2002: 818].

4 февраля 1828 г. в записке управляющему министерством иностранных дел К. В. Нессельроде сенатор Ф. И. Энгель отмечал необходимость продолжать развивать торговлю во Внутренней киргизской орде. Во время ревизии в 1827 г. он посетил урочища Ханская Ставка, Уялы и Чапчачи, выделенные специально под торговлю неместного населения с казахами. На него произвела впечатление сумма, вырученная в них от сбыта товаров, составившая в 1827 г. 2000000 руб., в связи с чем он заметил, что «Торговля сия важна и достойна особенного внимания и поощрения» [РГИА. Ф. 1291. ОП. 82. Д. 1. Л. 121-133об.].

Хан Джангир весьма успешно проводил политику сосредоточения торговой политики в своих руках. Он и лично разработал правила торговли, по которым он взял на себя обязательства выплачивать приезжим торговцам долги несостоятельных должников из числа своих подвластных [Евреинов 2001: 69], добился того, чтобы доходы с ярмарки в Ханской Ставке направлялись в его распоряжение, а после его смерти в 1845 г. - его наследникам, которые пользовались ими до 1863 г.; в этом году государство выкупило у них данное право, и ярмарочные доходы перешли в ведение коллективного органа управления Внутренней киргизской ордой - Временного совета [Иванов 2001в: 21]. В целях привлечения торговцев на постоянное место жительство в Ханской Ставке хан Джангир разрешил им брать бесплатно землю под строительство жилых и хозяйственных построек и распорядился продавать скот только оседлым жителям ставки и покупать товары только у них [Евреинов 2001: 45-46].

В 1832 г. правительство запретило приезжим вести разъездную торговлю среди казахов и тем самым вынудило их начать переход к стационарной торговле в отведённых для этих целей местах.

Меры стимулирующего характера, предпринятые ханом Джангиром в отношении торговли, способствовали увеличению числа пришлых торговцев и ремесленников в Ханской Ставке, которая в 1840-е гг., как пишет историк С. З. Зиманов, «превратилась в полном смысле слова в купече- ское селение» [Зиманов 1982: 73]. В конце 1840-х гг. в ней постоянно проживали 69 казахов (37 муж. и 32 жен.), 99 казанских татар (51 муж. и 48 жен.), 83 русских (38 муж. и 35 жен.) и 4 армян (3 муж. и 1 жен.). Более половины казахского населения принадлежала к высшей знати, среди русских большинство составляли занимавшиеся торговлей купцы, мещане и крестьяне, и 10 человек служили чиновниками, для казанских татар и армян главным родом деятельности была торговля [Бларамберг 1848: 13]. Зимой и во время проводившихся ярмарок население Ханской Ставки увеличивалось до нескольких сотен человек.

В середине XIX в. во Внутренней киргизской орде постоянно находилось 1000 астраханских и уральских казаков, которые несли службу в Ханской ставке, на Каспийской и Ахтубинской (астраханские казаки), Эльтонской и Новоузенской (уральские казаки) укрепленных линиях [Бекмаханова 1980: 127]. Большинство из них после отбытия смены, возвращались в родные станицы, но среди казаков имелась небольшая группа, постоянно проживавшая и занимавшаяся хозяйственной деятельностью на землях букеевских казахов.

Самой многочисленной среди этнических групп неказахского происхождения являлись татарская из Казанской губернии. По данным И. С. Иванова, помимо татар, постоянно проживавших в Ханской Ставке и на Глиняном форпосте, приблизительно 2000 казанских татар вели разъездную торговлю с казахами [Иванов 2001б: 123]. Последние, будучи татарам родственными по языку и религии, испытывали к ним доверия больше, чем к представителям других народов, поэтому коммерческие дела у татарских торговцев шли довольно успешно [Имашева 2014: 127]. Так, в 1893 г. из 28 действовавших в п. Ханская Ставка гильдейских торговых предприятий 20 принадлежали татарам - выходцам из Среднего Поволжья, а в 1909 г. из 141 торговых заведений 74 являлись татарскими. В 1909 г. в п. Новая Казанка татары владели 53-мя торговыми предприятиями из 93-х [Имашева 2014: 127].

По утверждению современного исследователя М. М. Имашевой, «торговцы-татары, несмотря на активную коммерческую деятельность, приобретение ими недвижи- 
мости в Орде, никогда окончательно не порывали связей с родиной, сохраняли национальный язык и обычаи» [Имашева 2014: 128]. Их дети учились только в татарских школах, они предпочитали заключать браки только с представителями своей этнической группы, молились в своих мечетях.

Татарские торговцы не только торговали, но и пропагандировали среди казахов ислам. Букеевские казахи до своего поселения в волго-уральских степях, хотя и исповедовали ислам, но знали его поверхностно, и влияние его на них было слабым. Татары-переселенцы способствовали укоренению ислама в казахской среде, причём большую помощь им в этом деле оказал хан Джангир. После его смерти в 1845 г. выяснилось, что правление Джангира было не столь полезным для России и казахов, как это виделось современниками при его жизни. Вскрылись множественные факты, злоупотребления властью со стороны хана и угнетения им своих подданных. «Но более всего нанесло вред России управление Джангера ${ }^{1}$, - писал генерал-губернатор Оренбургской и Самарской губерний В. А. Перовский в отношении от 23 декабря 1852 г. к министру государственных имуществ графу П. Д. Киселеву, - распространением в Орде магометанства, с которым дотоле масса киргизов была вовсе не знакома. Без существования в Орде хана Джангера слабая степень, в какой исламизм проник в класс султанов, могла бы совершенно изгладиться, и простой народ, не имевший никакой религии, тем доступнее оказывался бы к восприятию христианства» [История Букеевского ханства 2002: 814]. По его словам, «султанский класс в Орде успел он (т. е. Джангир) еще при жизни своей напитать враждебным всякому развитию мусульманским высокомерием...», а муллы стали «усердными распространителями нелепых слухов и первыми подстрекателями к неповиновению русской власти и русскому закону» [История Букеевского ханства 2002: 815].

На большую роль приезжих татар в исламизации казахского населения Внутренней киргизской орды указывал И. Сиротов, работавший в конце XIX - начале XX вв. в п. Новая Казанка учителем казахской школы министерства народного просвещения.

\footnotetext{
1 Так в источнике.
}

Он отмечал, что татары-торговцы активно распространяют среди казахов исламскую литературу, продают их в своих лавках и прямо на улице, заводят разговоры о религии во время торговли в своих лавках и в степи [Сиротов 1904: 208].

Активная пропаганда исламского вероучения велась в мусульманских школах, функционировавших в степи и в посёлках под различными названиями. Обучавшиеся в этих школах казахские дети, по утверждению И. Сиротова, «воспитывались в строгом духе ислама, в ненависти к христианству и вообще ко всему немусульманскому...» [Сиротов 1904: 210].

Мусульмане составляли большинство среди жителей поселков Внутренней киргизской орды, количество которых во второй половине XIX в. выросло до 3-х. Самым крупным среди них являлся административный центр Внутренней орды - Ханская Ставка. В первые годы XX в. в нём имелись 2 мечети, 1 православная церковь, 434 жилых и 467 нежилых построек, 162 торговые лавки и проживало 2648 чел. (1 424 муж. и 1274 жен.), в том числе 2075 казахов и татар и 568 русских [Поездка астраханского губернатора 1904]. Казахи в основном торговали мясом, содержали харчевни и постоялые дворы, работали прислугой; татары торговали различными товарами; русские были задействованы на государственной службе и также занимались торговлей.

Во второй половине XIX в. торговцами были основаны во Внутренней киргизской орде два новых поселения: Новая Казанка и Таловка. Первый поселок возник в 1871 г. в 20 верстах от административной границы Астраханской губернии с Уральской областью, при ставке правителя Камыш-Самарской части Внутренней орды, напротив упразднённого форпоста уральских казаков - Глининского. Посёлок расположился в удобном географическом месте - на пересечении торговых путей, идущих с юго-востока из г. Гурьева на северо-запад, к г. Александров Гай Самарской губернии. Кроме того, через Новую Казанку проходила дорога, связывающая восточную часть Внутренней киргизской орды и земли уральских казаков с административным центром букеевских казахов - Ханской Ставкой [Поленов 2001: 155]. 
Первыми жителями Новой Казанки были 32 семьи татар из Казанской губернии, торговавших на Глининском форпосте, располагавшемся напротив ставки правителя Камыш-Самарской части Внутренней киргизской орды. В 1871 г. форпост упразднили, и татары попросились перейти в ставку. Им разрешили, но без права пользования землёй и прописки. Вскоре к первопоселенцам стали присоединяться другие татары, а также казахи и русские. В 1886 г. Временный совет предоставил в пользование жителям Новой Казанки участок земли для выпаса молочного и рабочего скота, что улучшило условия существования поселенцев. К 1889 г. население Новой Казанки достигло 916 чел.; из них 485 чел. были татарами, 400 - киргизами и $31-$ русскими [Иванов 2001a: 154]. Превращению поселения в заметный торговый пункт способствовал ряд обстоятельств: удобное расположение на пересечении торговых путей, многочисленность кочевавшего в округе казахского населения и близость к населенным пунктам уральских казаков, что повышало потребности населения района в торговом обслуживании.

Основным родом деятельности жителей п. Новая Казанка являлась торговля. В 1904 г. во время посещения посёлка астраханским губернатором Б. Л. Гронбчевским было отмечено, что «Жители Новой Казанки занимаются исключительно торговлей, которая находится главным образом в руках татар. В последнее время некоторые русские торговые фирмы стали открывать здесь свои филиальные отделения и, таким образом, положили начало упрочению русского торгового элемента» [Поездка астраханского губернатора 1904]. В поселке имелось 201 торгово-промышленное заведение с годовым оборотом в 737000 руб., а годовые обороты по торговле скотом и продукцией животноводства достигали 332000 тыс., по рыбе до - 80000 руб. в год [Поездка астраханского губернатора 1904].

Казахское население посёлка самостоятельно торговые операции не вело, а выступало обычно посредником в сделках между татарами-торговцами и кочевавшими казахами. Недалеко от п. Новая Казанка находилось до 200 озёр, дававшие до 200000 руб. валового дохода от улова рыбы, поэтому часть её жителей успешно занималась ры- боловством [Поленов 2001: 157].

В первые годы XX столетия в п. Новая Казанка насчитывалось 281 жилых и 404 нежилых зданий, функционировали православная церковь и мечеть, 1 церковно-приходская, 1 русско-казахская, 2 казахских участковых школы и медресе, лечебница, проживали 1916 чел. [Поездка астраханского губернатора 1904].

Третьим по численности населенным пунктом Внутренней киргизской орды являлся п. Таловка. После упразднения в 1871 г. форпоста уральских казаков Таловского на его месте с разрешения оренбургского генерал-губернатора остались торговавшие здесь до этого 5 семей татар. С 1875 г. в поселке начали селиться с торговыми целями татары и русские, а также казахи, большинство из которых освоили ремесленные специальности (плотничное, кузнечное, сапожное и др.), ставшие источником их существования [Поленов 2001: 158]. Русские появились в Таловке из соседней с Внутренней киргизской ордой Самарской губернии и являлись самой многочисленной этнической группой среди жителей поселка. В самом начале XX в. из 1738 его жителей русскими были 737 чел., далее следовали казахи - 590 чел. и затем татары 276 чел. В 1897 г. в Таловке были построены православная церковь и церковно-приходская школа, имелись также мечеть и при ней медресе, лечебница и русско-казахская школа [Поездка астраханского губернатора 1904].

Поселившиеся во Внутренней орде торговцы и ремесленники основали в ней первые стационарные поселения и придали новый импульс развитию торговли, что способствовало приобщению к торговой и ремесленной деятельности казахов и, как следствие, переходу части их к оседлому образу жизни. Под влиянием торгово-ремесленной деятельности пришлого населения у казахов произошли изменения в социально-профессиональной структуре, в частности появился слой торговцев и ремесленников. Большинство из них порвали с кочевой жизнью и поселились в трёх упомянутых ранее поселках, или сами основали новые населенные пункты. Казахи-торговцы, например, полностью заселили п. Джамбай, выстроив в нём для стационарной торговли несколько лавок. Они также 
вдохнули жизнь в заброшенный п. Чапчачи, пришедший в упадок после закрытия соляного промысла. На рубеже XIX-XX вв. в нём проживало около 100 душ казахов и татар, которые занимались только торговлей, при этом преимущественно стационарной [Поленов 2001: 158].

Несмотря на своё успешное развитие, торгово-ремесленные поселения во Внутренней орде не имели органов управления, а большинство их жителей - прописки.

Поселковцы считались временно пребывающим в орде населением, хотя многие из них здесь родились и выросли, со всеми вытекающими отсюда ограничениями в правах. Им запрещалось предоставлять в пользование или в собственность земли, не разрешалось заниматься скотоводством и земледелием; за неисполнение установленных для них государством правил проживания во Внутренней киргизской орде власти могли их выселить из неё. Переселенцам удалось добиться только разрешения на право пользования небольшими участками земли возле поселков для содержания своего молочного и рабочего скота, необходимого для собственного пропитания и перевозки товаров.

В конце XIX в. власти приняли меры к упорядочению торговли в поселках, обложив её пошлиной, до этого она велась на основе ярмарочного права: налог уплачивался только за ярмарочные продажи. Во второй половине XIX в. известный исследователь истории и социально-экономической жизни посёлков И. С. Иванов отмечал хорошие перспективы их дальнейшего развития, но для этого, считал он, необходимо было ввести в поселках соответствующее общественное управление [Иванов 2001а: 155].

\section{Выводы}

В XIX в. территория Внутренней киргизкой орды не подвергалась сколь-нибудь значительному заселению со стороны оседлого населения из других губерний. Этому препятствовали как правовой статус казахских земель, которые по закону считались пожалованными императором Александром I в исключительное пользование букеевским казахам, так и тяжёлые природные условия, неблагоприятные для существования стационарных поселений и вообще для проживания человека. Не проявляло особого интереса к землям букеевских казахов и государство, поскольку через них не прохо- дили стратегически важные пути сообщения и ещё не были разведаны месторождения природных ископаемых, могущие быть использованными в промышленных целях. Не привлекали эти земли и крестьян, так как основная их часть была малопригодна или вообще непригодна к земледельческому освоению.

Перечисленные выше факторы не способствовали сколь-нибудь значительному развитию процесса переселений на земли Внутренней киргизской орды. В XIX в. на её территории возникло всего лишь 3 небольших по размерам населенных пункта, самым крупным среди которых являлся п. Ханская Ставка. Решающую роль в их создании сыграли торговцы, при этом важно отметить, что их появление и устройство на казахских землях стало возможным благодаря покровительственной торговой политике со стороны местной знати и властей.

Что касается государства, то оно не поощряло переселения торговцев и ремесленников на земли букеевских казахов, но в то же время и не препятствовало им. Иногородних торговцев привлекали во Внутреннюю киргизскую орду возможность получить большие прибыли от своей профессиональной деятельности, поддержка торговли высшим слоем казахской знати, отсутствие конкуренции со стороны местного населения в данном занятии. Последнее обстоятельство, а также близость языка и общая конфессиональная принадлежность к исламу способствовали занятию господствующего положения в сфере торговли татарскими переселенцами. Татары не только активно торговали, но и активно пропагандировали ислам, что привело к укреплению его позиций у казахов.

Торговцы и ремесленники фактически положили начало созданию стационарных поселений на землях букеевских казахов, способствовали развитию торговли и ремесел, приобщению кочевников к данным занятиям и к оседлому образу жизни. Документы свидетельствуют, что проникновение торговцев на территорию казахов Внутренний киргизской орды было обусловлено не целенаправленной политикой российского правительства и буржуазии с целью колониального порабощения казахского народа, как это утверждали марксистские историки и продолжают считать 
некоторые казахские историки, а вызвано благоприятными обстоятельствами для

\section{Источники}

ГА АО - Государственный архив Астраханской области.

РГИА - Российский государственный исторический архив.

\section{Sources}

State Archive of Astrakhan Oblast.

Russian State Historical Archive.

\section{Литература}

Альбрандт 2001 - Альбрандт Я. Букеевская Киргизская орда // Букеевской Орде 200 лет. Кн. 4 / науч. ред. М. Кулькенов. Алматы: Олке, 2001. С. 17-45.

Аспандияров 2007 - Аспандияров Б. А. Образование Букеевской Орды и её ликвидация. Алматы: Казак энциклопедиясы, 2007. 395 с.

Бекмаханова 1986 - Бекмаханова Н. Е. Многонациональное население Казахстана и Киргизии в эпоху капитализма (60-е годы XIX в. - 1917 г.). М.: Наука, 1986. 246 с.

Бекмаханова 1980 - Бекмаханова Н. Е. Формирование многонационального населения Казахстана и Северной Киргизии: последняя четверть XVIII - 60-е годы XIX в. М.: Наука, $1980.279 \mathrm{c}$.

Бларамберг 1848 - Бларамберг И. Ф. Военно-статистическое обозрение земель киргиз-кайсаков Внутренней (Букеевской) и Зауральской (Малой) орды Оренбургского ведомства. СПб.: Изд-во Военного министерства, 1848. 193 с.

Евреинов 2001 - Евреинов А. Внутренняя или Киргиз-Казачья орда // Букеевской Орде 200 лет. Кн. 4 / науч. ред. М. Кулькенов. Алматы: Олке, 2001. С. 30-86.

Зиманов 1982 - Зиманов С. З. Россия и Букеевское ханство. Алма-Ата: Наука, $1982.171 \mathrm{c}$.

Иванов 2001а - Иванов И. С. Внутренняя Киргизская Орда (Краткий статистический очерк) // Букеевской Орде 200 лет. Кн. 2 / науч. ред. М. Кулькенов. Алматы: Олке, 2001. C. 140-231.

Иванов 2001б - Иванов И. С. Хан Джангер, хан Внутренней Киргизской Орды // Букеевской Орде 200 лет. Кн. 2 / науч. ред. М. Кулькенов. Алматы: Олке, 2001. С. 5-139.

Иванов 2001в - Иванов И. С. Краткие сведения о ярмарке во Внутренней Киргизской орде // Букеевской Орде 200 лет. Кн. 4 / науч. ред. М. Кулькенов. Алматы: Олке, 2001. С. 20-28. торговой деятельности, сложившимися в данном регионе в XIX в.

Имашева 2014 - Имашева М. М. Торгово-предпринимательская и общественная деятельность татар во Внутренней киргизской орде Астраханской губернии (конец XIX - XX вв.) // Вектор науки Тольяттинского государственного университета. 2014. № 4 (30). C. $126-130$.

История Букеевского ханства 2002 - История Букеевского ханства. 1801-1852 гг. Сб. док-тов и мат-лов / сост. Б. Т. Жанаев, В. А. Иночкин, C. Х. Сагнаева. Алматы: Дайк-Пресс, 2002. 1120 с.

Киттара 2001 - Kитmара М. Я. Ставка хана Внутренней Киргизской орды // Букеевской Орде 200 лет. Кн. 3 / науч. ред. М. Кулькенов. Алматы: Олке, 2001. С. 5-38.

Поездка астраханского губернатора 1904 Поездка астраханского губернатора генерал-майора Б. Л. Гронбчевского во Внутреннюю Киргизскую Орду // Астраханский вестник. 1904. 21 мая.

Поленов 2001 - Поленов А. Пути торгово-промыслового движения в Букеевской орде и в пограничных с нею местностях // Букеевской Орде 200 лет. Кн. 6 / науч. ред. М. Кулькенов. Алматы: Олке, 2001. С. 46-242.

Сиротов 1904 - Сиротов И. Мусульманская пропаганда среди киргизов Букеевской Орды // Астраханские епархиальные ведомости. 1904. № 5. С. 208-211.

\section{Reference}

[A History of the Bukey Khanate: 1801-1852]. Coll. documents and materials. B. T. Ganev et al. (eds.). Almaty: Dayk-Press, 2002. 1120 p. (In Russ.)

A journey of the Astrakhan Governor General B. L. Grombchevsky to the Inner Kirghiz Horde. Astrakhanskiy vestnik. 1904, May 21. (In Russ.)

Albrandt J. The Bukey Horde of Kirghizes. In: [200 Years of the Bukey Horde]. Book 4. M. Kulkenov (ed.). Almaty: Olke, 2001. Pp. 1745. (In Russ.)

Aspandiarov S. A. [The Bukey Horde: Establishment and Annexation]. Almaty: Qazaq Entsiklopediasy, 2007. 395 p. (In Russ.)

Bekmakhanova N. E. [Formation of the Multinational Population of Kazakhstan and Northern Kyrgyzstan: mid-1770s to 1860s]. Moscow: Nauka, 1980. 279 p. (In Russ.) 
Bekmakhanova N. E. [The Multinational Population of Kazakhstan and Kyrgyzstan in the Capitalist Era: 1860 s to 1917]. Moscow: Nauka, 1986. 246 p. (In Russ.)

Blaramberg I. F. [Kirghiz-Kaisak Lands of the Inner (Bukey) and Trans-Ural (Minor) Hordes of Orenburg Department: a Military Statistical Review]. St. Petersburg: Ministry of War of the Russian Empire, 1848. 193 p. (In Russ.)

Evreinov A. The Inner, or Kirghiz-Kaisak, Horde. In: [200 Years of the Bukey Horde]. Book 4. M. Kulkenov (ed.). Almaty: Olke, 2001. Pp. 3086. (In Russ.)

Imasheva M. M. Trading, entrepreneurial and social activities of Tatars in the Inner Kirghiz Horde of Astrakhan Province (late $19^{\text {th }}-20^{\text {th }}$ centuries). Vector of Science of Togliatti State University. 2014. No. 4 (30). Pp. 126-130. (In Russ.)

Ivanov I. S. The Inner Kirghiz Horde: a brief statistical survey. In: [200 Years of the Bukey Horde]. Book 4. M. Kulkenov (ed.). Almaty: Olke, 2001. Pp. 140-231. (In Russ.)
Ivanov I. S. An overview of the trade fair in the Inner Kirghiz Horde. In: [200 Years of the Bukey Horde]. Book 4. M. Kulkenov (ed.). Almaty: Olke, 2001. Pp. 20-28. (In Russ.)

Ivanov I. S. Zhangir Khan - the ruler of the Inner Kirghiz Horde. In: [200 Years of the Bukey Horde]. Book 4. M. Kulkenov (ed.). Almaty: Olke, 2001. Pp. 51-39. (In Russ.)

Kittara M. Ya. The Inner Kirghiz Horde: Headquarters of the Khan. In: 200 Years of the Bukey Horde]. Book 4. M. Kulkenov (ed.). Almaty: Olke, 2001. Pp. 5-38. (In Russ.)

Polenov A. Trade routes in the Bukey Horde and adjacent territories. In: [200 Years of the Bukey Horde]. Book 4. M. Kulkenov (ed.). Almaty: Olke, 2001. Pp. 46-242. (In Russ.)

Sirotov I. Muslim propaganda among the Kirghizes of the Bukey Horde. Astrakhanskie eparkhial'nye vedomosti. 1904. No. 5. Pp. 208211. (In Russ.)

Zimanov S. Z. [Russia and the Bukey Khanate]. Alma-Ata: Nauka, 1982. 171 p. (In Russ.) 